\title{
Gene expression profiling of lymphoblastoid cell lines from monozygotic twins discordant in severity of autism reveals differential regulation of neurologically relevant genes Valerie W Hu*1, Bryan C Frank ${ }^{2}$, Shannon Heine ${ }^{1}$, Norman H Lee ${ }^{2}$ and John Quackenbush ${ }^{2,3,1}$
}

Address: ${ }^{1}$ The George Washington University Medical Center, Dept. of Biochemistry and Molecular Biology, 2300 Eye St., N.W. Washington, DC 20037, USA, ${ }^{2}$ The Institute for Genomic Research, 9715 Medical Center Drive, Rockville, MD 20850, USA and ${ }^{3}$ The Dana-Farber Cancer Institute, Department of Biostatistics and Computational Biology, 44 Binney St. Boston, MA 02115, USA

Email: Valerie W Hu* - bcmvwh@gwumc.edu; Bryan C Frank - bfrank@tigr.org; Shannon Heine - sheine@gwu.edu; Norman H Lee - nhlee@tigr.org; John Quackenbush - johnq@jimmy.harvard.edu

* Corresponding author

\section{Published: 18 May 2006}

BMC Genomics 2006, 7:118 doi:10.1186/147|-2164-7-118
Received: 04 January 2006

Accepted: 18 May 2006

This article is available from: http://www.biomedcentral.com/I47/-2164/7/II8

(C) 2006 Hu et al; licensee BioMed Central Ltd.

This is an Open Access article distributed under the terms of the Creative Commons Attribution License (http://creativecommons.org/licenses/by/2.0), which permits unrestricted use, distribution, and reproduction in any medium, provided the original work is properly cited.

\begin{abstract}
Background: The autism spectrum encompasses a set of complex multigenic developmental disorders that severely impact the development of language, non-verbal communication, and social skills, and are associated with odd, stereotyped, repetitive behavior and restricted interests. To date, diagnosis of these neurologically based disorders relies predominantly upon behavioral observations often prompted by delayed speech or aberrant behavior, and there are no known genes that can serve as definitive biomarkers for the disorders.

Results: Here we demonstrate, for the first time, that lymphoblastoid cell lines from monozygotic twins discordant with respect to severity of autism and/or language impairment exhibit differential gene expression patterns on DNA microarrays. Furthermore, we show that genes important to the development, structure, and/or function of the nervous system are among the most differentially expressed genes, and that many of these genes map closely in silico to chromosomal regions containing previously reported autism candidate genes or quantitative trait loci.

Conclusion: Our results provide evidence that novel candidate genes for autism may be differentially expressed in lymphoid cell lines from individuals with autism spectrum disorders. This finding further suggests the possibility of developing a molecular screen for autism based on expressed biomarkers in peripheral blood lymphocytes, an easily accessible tissue. In addition, gene networks are identified that may play a role in the pathophysiology of autism.
\end{abstract}

\section{Background}

Autism and related autism spectrum disorders (including Asperger's Syndrome and pervasive developmental disorder-not otherwise specified (PDD-NOS)) are considered to be among the most devastating psychiatric illnesses affecting children. The three core symptoms of autism spectrum disorders (ASD) are: 1 ) deficits in social interactions and understanding, 2) aberrant communication and/or language development, and 3) restricted interests and repetitive, stereotyped behaviors [1]. To date, there 
are no definitive molecular or genetic markers that allow unequivocal diagnosis of ASD, with the exceptions of tuberous sclerosis, Rett's Syndrome, and Fragile X Syndrome [2-12]. Together, these genetically defined mutations are present in only a minority of individuals $(<10 \%)$ within the broad autism spectrum. The majority of diagnoses are dependent on behavioral characteristics, according to DSM-IV guidelines, using questionnaires such as the Autism Diagnostic Interview-Revised (ADI-R) [13] or the Autism Diagnostic Observation Schedule (ADOS) [14], which are structured to evaluate children who are approximately 2 or older in mental age. Although the guidelines are relatively clear, the individual rater's (eg., parents, teachers, clinicians, therapists) perception of the evaluated behavior leaves much room for ambiguity. Moreover, with the more mildly affected individuals (eg., with Asperger's Syndrome), diagnosis is often not made until well after the child starts school and, even then, the child is often diagnosed with other more common disorders (such as attention deficit disorder or learning disability) before Asperger's Syndrome is considered, which delays appropriate intervention and effective educational programming. Thus, there is a great need to identify biomarkers that can be used consistently in a clinical setting to diagnose ASD. Furthermore, it is important to identify biological processes that are associated with distinct ASD phenotypes in order to design effective drug therapies targeted to specific individuals.

Although genetic linkage analyses have identified numerous candidate genes for autism [15], there is little consistent data that would support the use of any (or a combination) of these as diagnostic biomarkers for ASD. Furthermore, each candidate gene alone lends little insight into the pathophysiology of these disorders, which are believed to arise from dysregulation of multiple genes. Recently, attention has turned to transcriptional profiling approaches [16-19], which involve simultaneous, largescale expression analysis of thousands of genes on a cDNA (or oligonucleotide) microarray slide, to unravel complex psychiatric disorders. The advantage of transcriptional profiling using microarrays is the ability to study multiple genes in the context of functional gene networks within a living cell, as opposed to forward genetic approaches.

So far, application of microarrays to the study of autism has been described in just one study on post-mortem brain tissue from autistic subjects and matched tissue controls [20]. Thirty genes were identified as being differentially expressed in autistic brain samples relative to matched tissue controls on a combination of 2 separate array platforms containing 588 or 9374 cDNA probes, indicating that autism is associated with multiple disturbances in gene expression. Of this list, only a few genes related specifically to neurological functions and, of these, the glutamate receptor system was targeted for further study. In a similar vein, a recent bioinformatics analysis of autism positional candidate genes using biological databases and computational gene network prediction software demonstrates that the often disparate results from genetic studies implicating a multitude of different genes can be coalesced into interconnected but distinct pathways centered on a specific gene or genes (e.g., FOS and TP53), or on a particular biological theme, e.g., apoptosis [15]. Both of these studies suggest the involvement of multiple genes not previously associated with autism and illustrate the power of using a global approach to study this complex disorder.

The experimental strategy used in the study reported here was designed to tease out differences in gene expression among genetically identical individuals with ASD which might relate to observed differences in the degree of expression of autistic symptoms. Inasmuch as natural variations in gene expression are especially low for monozygotic twins $[21,22]$ (up to $1.76 \%$ in the latter study involving 10,000 genes in 5 pairs of monozygotic twins, compared to $\sim 14 \%$ in unrelated individuals), such a strategy has been shown to be useful in identifying candidate genes for bipolar disorder [23] and osteoporosis [24]. Moreover, lymphoblastoid cell lines (LCL) derived from blood cells of autistic individuals were used in this study to explore the possibility that biomarkers for autism could be expressed in easily accessible peripheral cells. Indeed, it has been reported previously that LCL from individuals with bipolar disorder displayed altered gene expression in both postmortem brain tissue and lymphoblasts, although one of the genes, LIM, was altered in the opposite direction in LCL [25]. Follow-up genetic association analyses of this gene demonstrated association of a single nucleotide polymorphism with bipolar disorder [26], indicating the usefulness of LCL and DNA microarray analyses in identifying potential biomarkers of a complex neurological disease.

While studies of gene expression in brain tissue may lead to a better understanding of the mechanistic basis for ASD, it is not an appropriate target for diagnostic assays. Ideally, diagnostic assays should use easily obtained patient samples such as blood, although there is no evidence that gene expression or other markers exist in the peripheral blood of ASD patients. However, one may hypothesize that ASD might arise, in part, through dysregulation of expression of specific neuronal genes and that expression differences between affected and unaffected individuals might be present in tissues other than brain. As a test of this hypothesis, we chose to use DNA microarray analysis to examine gene expression in LCL derived from peripheral blood lymphocytes. 
Here we report the first study using a genome-scale approach to identify biomarkers for autism. We demonstrate by gene expression profiling on DNA microarrays that: 1) LCL derived from five monozygotic twin pairs discordant for diagnosed autism and/or language impairment show differential gene expression; 2) a number of the most differentially expressed genes are present in pathways critical to the development and function of the nervous system; 3 ) there appears to be a quantitative relationship between the severity of the autistic phenotype exhibited by the twins and the expression level of certain genes relative to that of the respective genes in cell lines from non-affected siblings; and 4) approximately half of the most highly differentially expressed genes map in silico to previously reported chromosomal regions containing autism susceptibility genes or quantitative trait loci.

\section{Results \\ Differential gene expression in lymphoblastoid cell lines from monozygotic twins discordant for classic autism}

To determine whether LCL derived from individuals with autism exhibit patterns of gene expression that may be relevant to autism spectrum disorders (ASD), gene expression profiling was performed on LCL derived from 3 sets of male monozygotic twins, one of each pair who met standard diagnostic criteria for autism based on the ADIR. In each case, the other twin, while not clinically autistic, exhibited autistic traits and was classified either as "broad spectrum" or "not quite autistic" according to guidelines described by the Autism Genetic Resource Exchange (AGRE) repository. Two of the three twin pairs had an unaffected sibling and these were also used for comparison with their respective twin siblings. All of these assays employed an experimental design in which RNA from twin siblings were cohybridized on two-color spotted microarrays containing 39,936 human cDNA elements. Each microarray experiment involved dye-reversal replicates, and was performed in duplicate or, in one case, triplicate for the different sets of twins. The mean $\log _{2}$ ratios of each gene from the dye-reversal replicates were used for statistical analyses of the biological replicates.

Principal components analysis (PCA) of the combined microarray data with respect to samples from the 3 discordant twin sets showed that genotype is responsible for the major portion of the variation in differential gene expression, reflecting the expected transcriptome heterogeneity among unrelated individuals (see Additional file 1 ). The microarray data from the 3 sets of discordant twins was analyzed using SAM in order to identify genes that were significantly different from $\log _{2}=0$ across the biological replicates $(n=3)$. Twelve hundred genes were identified as significant with an FDR of $26 \%$. Twenty-five genes were found to be up-regulated at least 1.5-fold in the more severely affected twin relative to the other twin $\left(\log _{2}(\right.$ ratio $\left.)=0.58\right)$ and 19 genes were down-regulated by at least 1.5-fold (Table 1). Of these, eight of the 26 known genes (representing six unique genes) correspond to genes involved in neurological development, function, or disease. Because of this surprising finding, we used quantitative RT-PCR (qPCR) to confirm the differential expression of these specific genes (identified by boldtype in Table 1), as well as several with no known neuronal functions. As shown in Table 1, qPCR confirmed the relative expression levels of all but one of the tested genes, including neurologically relevant argininosuccinate synthetase (ASS), cell death-associated kinase (DAPK1), 5-lipoxygenase-activating protein (ALOX5AP or FLAP), interleukin-6 signal transducer (IL6ST), and Roundabout homolog 1 precursor (ROBO-1), as well as 3 of the "non-neuronal" genes including clotting factor XIIIa (F13A1), eukaryotic translation initiation factor 2C (EIF2C,2), and SAM domain, SH3 domain and nuclear localization signals, 1 (SAMSN1).

Moreover, when the expression profile of cells from the autistic twin was directly compared against that of his respective normal sibling in a dye-reversal microarray experiment, neurologically relevant genes represented 3 of the top 5 most differentially expressed genes (Table 2). Interestingly, the mean $\log _{2}$ (ratio) of each of these, ASS, CHL1, and FLAP, are higher for the autistic twin than for the more mildly affected twin when each is compared against their respective normal sibling, suggesting a quantitative relationship between differential gene expression (relative to normal individuals) and severity of autistic symptoms, at least for these specific genes. These quantitative differences have also been confirmed by qPCR analyses.

\section{Network prediction analysis shows interconnected pathways involving differentially expressed, neurologically relevant genes centered around inflammatory mediators}

Network prediction analysis using Ingenuity Pathways Analysis Software of the 1200 significant genes from the SAM analysis further revealed that 25 out of 58 network focus genes exhibiting a differential expression $= \pm 1$.5fold (i.e., $\log _{2}$ (ratio) greater than \pm 0.58 ) in at least one discordant twin set are involved in neurological function or disease (Table 3). This expression cutoff was selected because of reports in the literature suggesting that 1.47fold increases or decreases in gene expression are generally reproducible when Lowess normalization is used [27], and our own ability to confirm expression changes of at least 1.5 -fold by qPCR. Of particular note is the gene network that is derived from pathway analysis of the mean expression values (with $\log _{2}$ ratio $\geq \pm 0.58$ ) across 3 sets of discordant twins which shows that the majority of significantly differentially expressed genes are part of an extended network centered on TNF and other inflamma- 
Table I: Significant up- and down-regulated genes from SAM analysis of microarray experiments on 3 sets of monozygotic twins discordant for autism diagnosis with $\log 2$ (ratio) $\geq \pm 0.58$

\begin{tabular}{|c|c|c|c|}
\hline Genbank\# & Gene name or description & Mean $\log 2$ (ratio)* & qPCR \\
\hline & Upregulated $(\log 2($ ratio $) \geq 0.58)$ & & \\
\hline R45254 & Unknown protein & 1.19 & \\
\hline AA448599 & FI3AI, clotting factor XIIla precursor & 1.08 & 1.05 \\
\hline AA676466 & ASS, argininosuccinate synthetase (aa $|-4| 2$ ) & 0.92 & \\
\hline AA992985 & Unknown protein & 0.88 & \\
\hline AA676405 & ASS, argininosuccinate synthetase (aa $|-4| 2$ ) & 0.85 & 1.47 \\
\hline W07099 & NAGLU, N-acetylglucosaminidase, alpha & 0.85 & -0.28 \\
\hline AA044267 & $\mathrm{P} 2 \times 5 \mathrm{a}$ & 0.80 & \\
\hline$\underline{\mathrm{T} 49652}$ & FLAP, ALOX5AP & 0.79 & 1.01 \\
\hline$\underline{\mathrm{H} 57830}$ & histone $\mathrm{HI}(0)$ (aa I-194) & 0.78 & \\
\hline$\underline{\mathrm{R} 00276}$ & CD38 alt & 0.76 & \\
\hline$\underline{\mathrm{AA} 488070}$ & Unknown protein & 0.75 & \\
\hline W69399 & histone $\mathrm{HI}(0)$ (aa I-194) & 0.74 & \\
\hline$\underline{\mathrm{H} 09567}$ & PAGI & 0.74 & \\
\hline AA609189 & Unknown protein & 0.73 & \\
\hline$\underline{\mathrm{H} 02307}$ & FLAP, ALOX5AP & 0.70 & \\
\hline $\mathrm{N} 50114$ & PAGI & 0.69 & \\
\hline Al091671 & Unknown protein & 0.67 & \\
\hline N70181 & PLEKHGI & 0.66 & \\
\hline$\underline{\mathrm{H} 240 \mathrm{II}}$ & Homeodomain-like protein & 0.64 & \\
\hline$\underline{\mathrm{AA} 412520}$ & Unknown protein & 0.63 & \\
\hline$\overline{\mathrm{AA} 521362}$ & CR2 receptor & 0.62 & \\
\hline Al371096 & DAPKI, death-associated protein kinase I & 0.62 & 0.65 \\
\hline T61343 & IL6ST, IL6 signal tranducer, gp I 30 & 0.59 & 0.58 \\
\hline$\overline{N 29918}$ & ZBTBIO & 0.59 & \\
\hline \multirow[t]{2}{*}{$\underline{T 90067}$} & $\mathrm{EIF} 2 \mathrm{C} 2$ & 0.59 & 0.99 \\
\hline & Downregulated $(\log 2($ ratio $) \leq-0.58)$ & & \\
\hline$\underline{\mathrm{T} 67053}$ & IGLC2 & -2.39 & \\
\hline W73790 & IGLLI & -2.00 & \\
\hline$\underline{\mathrm{H} 18423}$ & Unknown protein & -1.98 & \\
\hline AA448157 & CYPIBI & -0.95 & \\
\hline AA644099 & Unknown protein & -0.89 & \\
\hline AA933744 & ECATII & -0.84 & \\
\hline Al018127 & Unknown protein & -0.83 & \\
\hline AA451886 & CYPIBI & -0.77 & \\
\hline AA682565 & Unknown protein from neuroblastoma & -0.72 & \\
\hline Al223429 & Unknown protein & -0.69 & \\
\hline AA450353 & ELMODI & -0.69 & \\
\hline AA873578 & IGHGI & -0.67 & \\
\hline R33402 & SAMSNI & -0.67 & -0.61 \\
\hline AAI73755 & ROBOI, roundabout I & -0.66 & -0.93 \\
\hline AA022886 & retinal degeneration $B$ beta & -0.64 & \\
\hline AA063573 & SAMSNI & -0.64 & \\
\hline H99699 & mitochondrial aconitase & -0.63 & \\
\hline Al290663 & CYBASC3 & -0.60 & \\
\hline AA449333 & Rab22b & -0.58 & \\
\hline
\end{tabular}

*Mean $\log _{2}$ (ratio) of gene expression in lymphoblastoid cell lines from children exhibiting classic autism to cell lines from less affected monozygotic twin sibs. SAM analysis revealed I 200 significant genes with an FDR of $26.4 \%$. Only genes for which microarray data is available for all 3 sets of twins are included in this table.

¥Mean $\log _{2}$ (ratio) of qPCR data from 3 sets of monozygotic twins. Gene expression was analyzed in triplicate assays (or duplicate for FI3AI,

EIF2C2, and SAMSNI) and the mean $\log _{2}$ (ratio) for each respective gene was averaged among the 3 sets of twins. Only one gene, NAGLU, out of the 9 tested from this table was not confirmed by qPCR, possibly because of suboptimal choice of primers for qPCR.

Genes in boldface type have been shown to be relevant to neurological development, structure, or function (See Table 3). 
Table 2: Expression of ASS, CHLI, and FLAP in 2 sets of discordant monozygotic twins relative to expression levels in their respective normal siblings

\begin{tabular}{llllll}
\hline Gene name & Genbank \# & Al & MI & A2 & M2 \\
\hline ASS & $\underline{\text { AA676405 }}$ & $0.65(0.8 I)^{*}$ & $-0.13(0.27)$ & $1.77(3.04)$ & $0.18(0.97)$ \\
CHLI & $\underline{\text { TI5267 }}$ & $1.60(1.64)$ & $0.67(1.39)$ & $1.15(0.78)$ & $0.95(0.60)$ \\
FLAP & $\underline{\text { T49652 }}$ & $0.71(1.10)$ & $0.13(0.77)$ & $1.40(1.45)$ & $-0.09(-0.39)$ \\
\hline
\end{tabular}

Values are mean $\log _{2}($ ratio) measures of gene expression between a twin and his respective normal sibling, obtained by DNA microarray analyses with dye reversal replicates

* Values in parentheses are mean $\log _{2}$ (ratio) measures obtained by triplicate qPCR analyses.

$A=$ autistic twin as diagnosed by ADI-R scoresheet

$M=$ more mildly affected twin who did not meet ADI-R criteria for autism

tory mediators (Fig. 1). The neurological functions of 8 of the genes in this network are described in Table 3, which lists all of the network focus genes that exceed the differential expression cutoff (1.5-fold increase or decrease) in at least 1 pair of twins. In comparing this list to that of Table 1, it is clear that, aside from overlapping differentially expressed genes across the 3 sets of twins, there are network genes that are uniquely up- or down-regulated within each of the twin pairs, as illustrated by Additional file 2. The collective data from the above-mentioned microarray and pathway analyses suggested a short list of novel candidate autism susceptibility genes with reported neurological functions for further evaluation.

\section{Differential expression of autism candidate genes in "concordant" autistic twins}

Expression analysis of autism candidate genes in LCL from two sets of twins in which both individuals were diagnosed as autistic surprisingly showed differential expression of several of the candidate genes (Table 4). However, in each case, the "concordant" autistic twin siblings were found to be discordant with respect to severity of language impairment based on each twin's scores on the Peabody Picture Vocabulary Test (PPVT) (see Additional file 3 for profile of subjects studied). Thus, when microarray data from the more language-impaired twin (lower percentile PPVT score) was compared relative to the less impaired twin, the differential gene expression profile overlapped with that which was obtained from the "discordant" twin sets. This result underscores the importance of considering autistic phenotype and/or severity as a means of reducing heterogeneity of gene expression in the search for biomarkers of autism. Interestingly, as shown in Table 4, expression analysis of the candidate genes in cells from monozygotic nonautistic twins demonstrated that two of the genes, CHL1 and possibly ROBO1, were differentially expressed. However, it is worth noting that this set of "normal" twins has two autistic siblings. Thus, it is not clear to what extent their gene expression profiles are "normal" since autism exhibits strong genetic influences. It is therefore possible that the differential expression of these two neurologically relevant genes is not coinciden- tal, but does not, by itself, meet the threshold for association with an autistic phenotype. Alternatively, this result might suggest that these genes are not involved in autism. Clearly, this observation on only one set of normal twins warrants future investigation preferably with twins with no autism in their family background. At this time it is difficult to obtain normal monozygotic twins with no autistic siblings from the AGRE repository which focuses exclusively on collecting samples from pedigrees with familial autism.

\section{The serotonin transporter (5-HTT) gene is also differentially expressed in lymphoblastoid cells from monozygotic twins discordant in severity of autism and/or language impairment}

To evaluate whether differential expression of the serotonin transporter (5-HTT), which is strongly implicated in autism, can be detected in LCL from the autistic and nonautistic twins, qPCR analyses were performed, as 5-HTT is not represented on the microarray platform. Results indicated that, while there is no difference in 5-HTT expression between the nonautistic twins, there is a significant decrease in expression in the more severely affected twin in all of the autistic twin pairs studied, as shown in Table 4. Reduced expression of 5-HTT in blood-derived cells may explain hyperserotonemia in a subset of autistic individuals [28]. It should also be noted that a polymorphism in the promoter region of 5-HTT which results in reduced transcription of 5-HTT is a factor in anxiety-related traits $[29,30]$, common in autism. The present finding suggests that LCL, or their precursor blood lymphocytes, may be useful as reporter cells to evaluate neurologically relevant gene expression differences between autistic and normal individuals.

\section{Network and global functional analyses of the pooled microarray data on monozygotic twins with autism highlight genes involved in nervous system development and function}

Because of the observed relationship between severity of symptoms and differential expression of candidate genes across the 5 autistic twin pairs studied, SAM was applied 
Table 3: Network focus genes from Ingenuity Pathways Analysis meeting differential expression cutoff of log2(ratio) $\geq \pm 0.58$ ( 1.5 -fold increase or decrease) in at least I set of twins.

\begin{tabular}{|c|c|c|}
\hline GenBank \# & Gene & Neurological function or disease* \\
\hline \multicolumn{3}{|l|}{ Upregulated } \\
\hline $\mathrm{T} 49652$ & ALOX5AP & neuronal signaling; possibly neurodegenerative diseases \\
\hline AA991590 & $\mathrm{APOCI}$ & \\
\hline AAI47I70 & ALS4 & ataxia-ocular apraxia \\
\hline AA676466 & ASS & involved in nitric oxide production \\
\hline$\underline{\mathrm{H} 2104 \mathrm{I}}$ & ATF3 & extension of neurites \\
\hline AA702350 & AUTS2 & Asperger's syndrome \\
\hline $\mathrm{Al} 34 \mid 427$ & BCATI & \\
\hline AA430367 & CBS & \\
\hline R00276 & CD38 & \\
\hline AA283949 & CDCI4A & \\
\hline N67039 & CDK6 & \\
\hline$\overline{\mathrm{HI}} 5267$ & CHLI & extension of neurites; organization of mossy fibers \\
\hline AA521362 & CR2 & \\
\hline$\overline{\mathrm{AA} 884403}$ & CTFI & myelination, differentiation of neurons \\
\hline $\mathrm{A} 1371096$ & DAPKI & apoptosis of hippocampal neurons \\
\hline$\overline{W 00789}$ & DST & coalignment of neurofilaments, projection of axons; dysmyelination \\
\hline AA448599 & FI3AI & stroke \\
\hline AAI49640 & FLTI & VEGF-induced release of nitric oxide \\
\hline$\overline{\mathrm{AA} 070902}$ & GGA2 & \\
\hline $\mathrm{A} 1375302$ & HMGB I & extension of neurites \\
\hline $\mathrm{Al} 539460$ & IL7 & \\
\hline AA406546 & IL6ST & myelination, development of motor neurons, retraction of dendrites \\
\hline H09062 & MLSTDI & \\
\hline$\overline{\text { W07099 }}$ & NAGLU & neurogenesis; vacuolation of neurons \\
\hline$\overline{\mathrm{AA} 598611}$ & NR4A2 & neurogenesis; metabolism of dopamine \\
\hline AA707195 & NTRK2 & survival of Purkinje cells; apoptosis of neurons \\
\hline AA044267 & $\mathrm{P} 2 \mathrm{R} \times 5$ & \\
\hline$\underline{\mathrm{H} 09567}$ & PAG & possible role in chronic neuroinflammation \\
\hline AA972337 & PAWR & \\
\hline AA489629 & PBEFI & \\
\hline $\mathrm{A} 1016039$ & PLXNB2 & \\
\hline $\mathrm{R} 80217$ & PTGS2 & activation of astrocytes; spatial memory in mice; apoptosis of neurons \\
\hline$\overline{\mathrm{AA} 495950}$ & RRM2B & \\
\hline R27457 & SLC38A2 & \\
\hline $\mathrm{A} 1091460$ & SOSI & \\
\hline N63153 & SPREDI & \\
\hline $\mathrm{Al} 040821$ & TEREI & \\
\hline AA970358 & TSLP & \\
\hline \multicolumn{3}{|c|}{ Downregulated } \\
\hline AA779727 & ADAMI9 & development of septum \\
\hline R01732 & AMPD3 & \\
\hline AA478589 & APOE & quantity/morphology of neurons; neurite extension; learning in mice \\
\hline AA984646 & C7orf2 & \\
\hline AA448157 & CYPIBI & \\
\hline AA446027 & EGR2 & myelination; development of motor neurons; routing of axons \\
\hline AAI49096 & $\mathrm{HCK}$ & \\
\hline AA6205II & HSPA8 & \\
\hline W73790 & IGLLI & \\
\hline $\mathrm{Al} 380522$ & ITGB7 & chronic demyelinating disease \\
\hline$\overline{\mathrm{AA} 679503}$ & KIFIB & morphology and size of brain; neuron survival \\
\hline AA029283 & LARGE & \\
\hline$\underline{T 83159}$ & LSPI & \\
\hline $\mathrm{A} 1351740$ & LTB & neurological disorder in rats \\
\hline AA022886 & PITPNCI & \\
\hline All26054 & PTK2 & \\
\hline AA173755 & ROBOI & axon guidance \\
\hline$\overline{\mathrm{AA} 457700}$ & SCD & neural regeneration \\
\hline
\end{tabular}


Table 3: Network focus genes from Ingenuity Pathways Analysis meeting differential expression cutoff of log2(ratio) $\geq \pm 0.58$ ( 1.5 -fold increase or decrease) in at least I set of twins. (Continued)

\begin{tabular}{ll}
\hline AA5042II & TNFSFII \\
\hline U68465 & UAPI
\end{tabular}

Dataset included 1200 significant genes identified by SAM across three twin sets. FDR was $26.4 \%$.

Genes in Boldfaced type are ones of neurological relevance.

*Descriptions of neurological functions were obtained from the Ingenuity Pathways Knowledge Base.

to microarray data from all 5 sets of twins to identify genes that were significantly up- or down-regulated across all twin pairs, each pair of which exhibited differential severity with respect to language ability (Table 5). Once again, pathway analysis of the differentially expressed significant genes revealed an extended network centered on TNF and other cytokines (including IL1B, IL4, and IL6, which was highly expressed in the brain tissues of autistic individuals [34]), connecting a number of neurologically relevant genes (Fig. 2). Global functional analysis of the 1281 significant differentially expressed genes from 5 pairs of twins further shows that genes related to "nervous system development and function" are among the most statistically significant, enriched genes across the 5 sets of twins (Table 6).

\section{In silico mapping of differentially expressed genes to chromosomal regions containing autism candidate genes or quantitative trait loci (QTL)}

Although most of the differentially expressed genes identified in this study are novel candidate genes with respect to autism, Table 7 shows that 6 out of 8 of the candidate genes listed in Table 4 [and approximately half (55\%) of the differentially expressed genes listed in Tables 3 and 5 (see Additional file 4)] map within or close to chromosomal regions containing previously reported autism candidate genes (ACG) or recently identified QTL for language and nonverbal communication. Interestingly, as observed in Additional File 4 and Table 7 respectively, 32$50 \%$ of the genes mapped in silico to autism susceptibility or quantitative trait loci are located within language QTL recently identified by Alarcon et al [59], perhaps reflecting the differential severity of language impairment between the co-twins in this study. This observation suggests that the overlay of expression data onto genetic data allows one to focus further genetic and functional analyses on expressed, neurologically relevant genes that may relate to the behavioral phenotype. Taken together with the network and global functional analyses described above, these results suggest that blood-derived cells may be useful as surrogates to screen for biomarkers for autism.

\section{Discussion}

These studies provide a novel approach to determining candidate genes for autism through the use of peripheral cell lines derived from individuals with ASD. The observations represent a model for the development of a diagnos- tic screen for autism based on biomarker detection in blood, which is an easily accessible tissue.

In this study, DNA microarrays containing 40 K human cDNA probes were utilized to examine differences in gene expression profiles in LCL derived from 5 pairs of monozygotic twins with ASD. Three sets of twins were discordant with respect to clinical diagnosis of autism, and 2 sets (with both co-twins diagnosed as autistic) differed with respect to severity of language impairment. We specifically chose this experimental model (direct comparison of identical twins) because differential gene expression in blood leukocytes from monozygotic twins has been reported to be much more restricted than between unrelated controls and, furthermore, the differentially expressed genes exhibited "random variations", showing no specific preference for any functional class [22]. The most remarkable finding of this study is that global functional analysis of the significant differentially expressed genes in LCL from these 5 sets of twins identifies "Nervous system development and function" as a top "high level function" that is significantly enriched across the 5 gene expression datasets (Table 6). Moreover, in silico mapping of our most differentially expressed genes across as well as within the twin sets demonstrates that many of these genes are located in or close to chromosomal regions previously identified as autism susceptibility loci by genetic analyses (Table 7 and Additional file 4). Quantitative RT-PCR analysis has further confirmed the differential expression of a subset of our novel candidate genes in the majority of twin sets studied.

Several of these candidate genes and their associated gene networks may provide insight into potential mechanisms involved in the autistic phenotype(s). One of the striking results of the pathway analyses is that a relatively large number of the differentially expressed, neurologically relevant genes are linked in networks that are centered on genes involved in inflammation (see Figs. 1 and 2). The network genes with reported neurological functions include the proteins ASS, ALOX5AP (FLAP), CD44, CHL1, DAPK1, EGR2, F13A1, FLT1, IL6ST, NAGLU, PTGS2, and ROBO1 (See Table 3). The protein ASS regulates the ratelimiting step involved in nitric oxide (NO) production through regeneration of arginine from citrulline, a byproduct of the nitric oxide synthetase (NOS) reaction [31]. Since NO is a major signaling molecule in the brain 


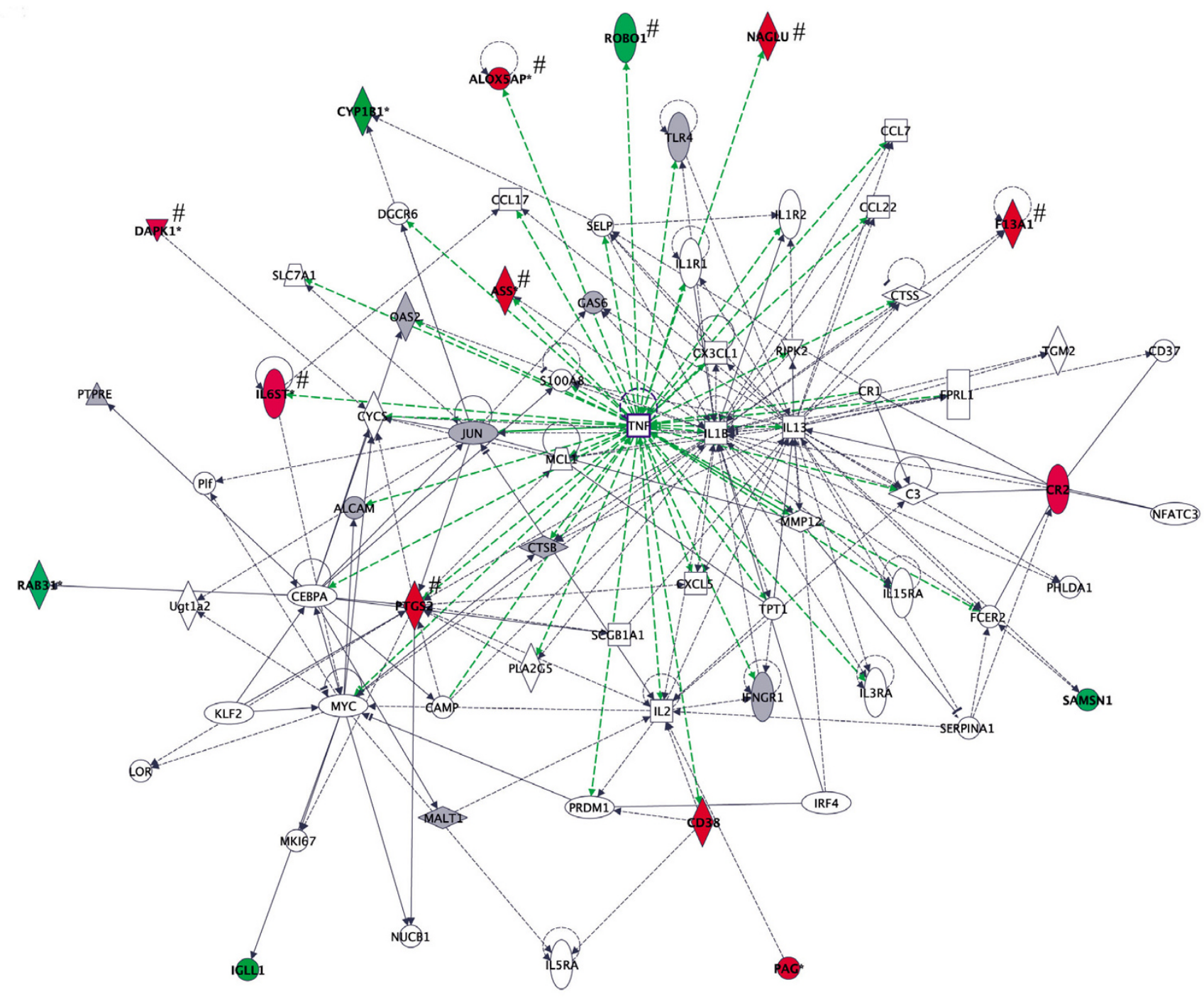

Figure I

Gene networks showing inter-relationship between differentially expressed genes in LCL from 3 discordant autistic twin sets using Ingenuity Pathways Analysis software. The over-expressed (red) and under-expressed (green) genes were identified as significant using SAM analysis (FDR $=26.4 \%$ ) of microarray data across 3 twin pairs. The log 2 expression ratio cutoff was set at \pm 0.58 and was based upon the mean values for each gene. Genes within this network that have a reported role in nervous system development and function are marked with a "\#" symbol and include: ASS, ALOX5AP (FLAP), DAPKI, FI3AI, IL6ST, NAGLU, PTGS2, and ROBOI. Gray genes are present but do not meet expression cutoff.

that has been implicated in several psychiatric disorders, including autism [32], the increased expression of ASS may be of potential relevance to the autistic phenotype. ASS has also been shown to be induced in a rat model of brain inflammation [33], which would be consistent with the hypothesis that neural inflammation may play a role in autism [34]. DAPK1, a cell death-associated serine/threonine kinase which is involved in suppression of integrin activity and disruption of matrix survival signals [35], is also induced by inflammation [36]. Interestingly, the expression of FLT1 (VEGF receptor 1) is also regulated by inflammatory cytokines as well as by NO [37]. Furthermore, the fact that IL6ST (gp130) is increased in LCL from the more severely affected twin, may complement previous observations that IL- 6 is the most elevated inflammatory cytokine in the middle frontal gyrus and anterior cingulate gyrus of brain autopsy tissue from autistic individuals [34]. While upregulation of ASS, DAPK1, FLT1, and IL6ST may be responses to inflammation, ALOX5AP (FLAP) and PTGS2 (COX-2) mediate inflammation 
Table 4: Relative expression of candidate genes in monozygotic "concordant" twin pairs with differential language impairment (PPVT percentile scores) and in normal twins

\begin{tabular}{|c|c|c|c|c|c|}
\hline Candidate Gene & Genbank \# & PPVT - 30/42* & PPVT - 0.1/I & Discordant twins $¥$ & Normal twins \\
\hline ASS & $\underline{\mathrm{AA} 676405}$ & $0.03(-0.26)^{\#}$ & $-0.01(-0.69)$ & $0.85(1.47)$ & $0.24(0.54)$ \\
\hline $\mathrm{CHLI}$ & $\mathrm{HI} 5267$ & $1.83(1.48)$ & $1.99(1.29)$ & $0.56(0.46)$ & $1.40(1.45)$ \\
\hline IL6ST & $\underline{\mathrm{T} 61343}$ & $0.88(1.33)$ & $0.28(-0.26)$ & $0.59(0.58)$ & $0.37(0.23)$ \\
\hline IL6ST & AA406546 & $1.02(0.85)$ & $0.34(-0.14)$ & $0.58(0.6 \mathrm{I})$ & $0.43(0.47)$ \\
\hline DAPKI & $\mathrm{Al} 371096$ & $-0.56(-0.92)$ & $-0.49(-1.05)$ & $0.62(0.65)$ & $-0.13(-0.18)$ \\
\hline FLAP & $\underline{\mathrm{T} 49652}$ & $1.18(1.20)$ & $0.28(-0.25)$ & $0.79(0.58)$ & $-0.19(-0.34)$ \\
\hline ITGB7 & $\mathrm{Al} 380522$ & $-1.12(-1.13)$ & $-0.20(-0.92)$ & $-0.56(-0.76)$ & $0.15(0.04)$ \\
\hline EGR2 & AA446027 & $-2.02(-3.10)$ & $-1.26(-2.16)$ & $-0.40(-0.79)$ & $-0.23(-0.37)$ \\
\hline ROBOI & $\underline{\mathrm{AA} 173755}$ & $-0.13(0.25)$ & $0.41(-0.18)$ & $-0.66(-0.93)$ & $-0.45(-0.80)$ \\
\hline 5-HTTा & BC069484 & NPI $(-2.39)$ & NP $(-0.42)$ & NP $(-0.96)$ & NP $(-0.02)$ \\
\hline
\end{tabular}

*Values represent the mean log2(ratio) of gene expression from DNA microarray data from 2 sets of monozygotic autistic twins who both met criteria for autism by either ADOS or ADI-R diagnostic tests, but have differential language impairment as indicated by their respective PPVT percentile scores. Data from 2 separate dye-reversal microarray experiments were averaged for each twin set. For each pair of twins, microarray data from the twin with the lower PPVT score was used as the numerator in calculating the gene expression ratio. PPVT - $30 / 42$ refers to the twin pair whose PPVT percentile scores are 30 and 42, while PPVT $-0.1 / I$ refers to the twin pair whose percentile scores are 0 .I and I. Interestingly, the two sets of twins share the same mother. The PPVT-30/42 set are Caucasian males, as are the 3 sets of discordant twins, while the more severely language-impaired twins (PPVT -0.I/I) are black, Latino males.

\#Values in parentheses are mean $\log _{2}$ (ratio) expression measures obtained by triplicate qPCR analyses.

$¥$ Mean expression value across 3 sets of twins discordant for diagnosis of classic autism.

๓Not present (NP) on microarray

through the production of leukotrienes [38] and prostaglandins [39]. Interestingly, 5-lipoxygenase, the target of FLAP activation, has been implicated in aging and neurodegenerative diseases [40], as well as other psychiatric disorders [41], including anxiety and depression, which are frequently co-morbid conditions of autism, while a COX2 inhibitor, celecoxib, has been shown to have therapeutic effects in major depression [42], further suggesting a role for inflammatory processes in psychiatric disease. Collectively, the potential involvement of these specific genes that are associated with neurological function and disease and their presence in pathways regulated by inflammatory mediators lend further support to the neural inflammation model for autism [34], which may be also manifested by immune dysfunctions commonly observed in autism [43].

In addition to the possible role of genes involved in inflammation, a review of the gene list in Table 3 suggests several additional recurring biological themes among the differentially expressed genes with neurological functions: neuronal survival, neurite extension/guidance, and myelination. In this regard, altered expression of EGR2, the most down-regulated gene across 5 twin sets, may be particularly significant (See Table 5 and Additional file 2). EGR2 (Krox-20) is a transcription factor involved in the development of the brain and peripheral nervous system, routing of axons, and myelination [44,45]. Some of these functions may be related to EGR2-mediated regulation of ROBO1, which is involved in neuronal differentiation and axon guidance $[46,47]$, and integrin beta-7 (ITGB7) which has been implicated in chronic demyelinating disease [48]. The expression levels of all three of these genes are relatively reduced with increased severity of autism or language impairment (Table 4). The involvement of cell migration in the pathophysiology of autism is also implicated by the altered expression of CHL1, a novel neural cell adhesion molecule that is involved in neurite migration, outgrowth, connectivity, and survival. Deficiency in CHL1 has been shown to be associated with mental and motor impairments as well as with alterations in exploratory and emotional behavior in mice $[49,50]$, characteristics that are often associated with autism. However, the effect of CHL1 overexpression, which we observe to be associated with the more severe phenotype, has yet to be determined. While the function of such neurologically relevant genes in lymphoblastoid cell lines is unknown, there is growing evidence that gene expression is under genetic control in LCL, as well as in other cells, with one study showing that $31 \%$ of the differential expression in LCL among unrelated individuals was heritable [21]. Thus, it is reasonable to postulate that hereditary factors that are responsible for the development of the autistic brain might also be manifested in the LCL as differentially expressed genes. If expression of these genes can be shown to be consistently altered in LCL in case-control studies on a larger sample of unrelated individuals, these cells, and by inference their precursor blood lymphocytes, can potentially be used as reporter cells for diagnosis of ASD. While we have focused on differentially expressed genes of neurological relevance in this study, it should be noted that the biomarkers for autism in LCL or lymphocytes 
Table 5: Significant genes exceeding expression cutoff across 5 sets of twins with ASD

\begin{tabular}{|c|c|c|}
\hline Genbank\# & Gene name or description & $\begin{array}{c}\text { Mean } \\
\log _{2} \\
\text { (ratio)* }^{*}\end{array}$ \\
\hline & Upregulated $(\log 2($ ratio $) \geq 0.58)$ & \\
\hline AA448599 & FI3AI, clotting factor XIIla precursor & 1.50 \\
\hline HI5267 & CHLI, neural cell adhesion molecule & 1.10 \\
\hline AA521362 & CR2 receptor & 1.07 \\
\hline R00276 & CD38 alt & 0.83 \\
\hline W07099 & NAGLU, N-acetylglucosaminidase, alpha & 0.77 \\
\hline T49652 & FLAP, ALOX5AP & 0.77 \\
\hline AA044267 & $\mathrm{P} 2 \times 5 \mathrm{a}$ & 0.76 \\
\hline R40400 & CHLI, neural cell adhesion molecule & 0.75 \\
\hline$\overline{\mathrm{H} 09567}$ & PAGI & 0.71 \\
\hline Al400399 & CYP7BI & 0.70 \\
\hline$\underline{\mathrm{AAI}} 49640$ & FLTI & 0.67 \\
\hline HI7800 & Unknown protein & 0.67 \\
\hline $\mathrm{H} 02307$ & FLAP, ALOX5AP & 0.67 \\
\hline AA917693 & Unknown protein & 0.66 \\
\hline $\mathrm{A} 1017382$ & ATXN7LI & 0.66 \\
\hline Al091671 & Unknown protein & 0.65 \\
\hline $\mathrm{N} 50114$ & PAGI & 0.65 \\
\hline H95977 & Nmd protein, PLAIA & 0.65 \\
\hline AA040389 & Unknown protein & 0.64 \\
\hline$\underline{\mathrm{H} 24011}$ & Homeodomain-like protein & 0.64 \\
\hline$\underline{\mathrm{A} 1275120}$ & Unknown protein & 0.63 \\
\hline AA708955 & SCHIPI, schwannomin interacting protein I & 0.62 \\
\hline AA406546 & IL6ST, IL6 signal transducer, gp I30 & 0.62 \\
\hline R79082 & PTPRK & 0.59 \\
\hline Al24I34I & CHLI, neural cell adhesion molecule & 0.59 \\
\hline \multirow[t]{2}{*}{$\mathrm{T} 61343$} & IL6ST, IL6 signal transducer, gp I 30 & 0.59 \\
\hline & Downregulated $(\log 2($ ratio $) \leq-0.58)$ & \\
\hline AA446027 & EGR2, Krox-20 homolog & -0.90 \\
\hline AA630734 & seryl-tRNA synthetase & -0.86 \\
\hline$\underline{\mathrm{R} 47893}$ & CCL3LI & -0.80 \\
\hline AA682565 & Unknown protein from neuroblastoma & -0.76 \\
\hline$\underline{\mathrm{R} 78530}$ & COTLI & -0.73 \\
\hline AA933744 & ECATII & -0.73 \\
\hline N58443 & GPR55 & -0.68 \\
\hline$\underline{\mathrm{H} 99699}$ & mitochondrial aconitase & -0.64 \\
\hline$\overline{\mathrm{H} 03494}$ & CD44 & -0.63 \\
\hline$\underline{\mathrm{AA} 450353}$ & ELMODI & -0.63 \\
\hline AA458965 & IL32, natural killer cell protein, transcript 4 & -0.63 \\
\hline R33402 & SAMSNI & -0.62 \\
\hline AAIII969 & CD83 antigen & -0.60 \\
\hline $\mathrm{Al} 380522$ & ITGB7, integrin beta-7 subunit & -0.60 \\
\hline AA682637 & $\mathrm{CHST} 2$ & -0.59 \\
\hline
\end{tabular}

*Mean $\log _{2}$ (ratio) of gene expression across 5 sets of twins with ASD. SAM analysis revealed I28I significant genes with a median FDR of $15.6 \%$. Only genes for which microarray data is available for all 3 sets of twins are included in this table. Genes in boldface type have been shown to be relevant to neurological development, structure, or function.

need not have specific neurological functions (as we have also detected and confirmed differential expression of "non-neuronal" genes). Given that ASD is most probably a multigene disorder of varying etiology, a biomarker screen for ASD would likely include a panel of genes consistently associated with ASD phenotypes, in which diagnosis for the disorder will depend upon differential expression of a defined percentage of genes within the consensus set.

The observed relationship between differential gene expression and severity of ASD between monozygotic twins suggests a role for epigenetic factors in ASD. A recent report on normal monozygotic twins indicates that epigenetic differences arise over time, increasing with age and with physical separation from each other after birth [45]. Indeed, epigenetic differences between monozygotic twins have been examined as possible causes for discordancy in schizophrenia as well as bipolar disorder [5153]. Possible epigenetic mechanisms leading to differences in gene expression include differential methylation, differences in histone acetylation, and micro RNA, although there is no available evidence linking any of these to autism at this time. On the other hand, a mutation in a methyl-CpG binding protein, X-linked MeCP2, has been identified as being involved in $80 \%$ of all cases of Rett Syndrome [54], a developmental disorder which overlaps ASD, thus implicating the importance of methylation-dependent gene expression in at least this related disorder. Interestingly, though ubiquitously expressed [55], mutated MeCP2 induces a specific neuronal dysfunction, i.e., Rett Syndrome. One could therefore postulate that differential methylation or differential histone acetylation might give rise to differential expression in LCL from monozygotic twins with ASD and test for global changes in methylation or histone acetylation as done by Fraga et al [45], or for specific changes within a given candidate gene. Such epigenetic modifications in turn could be in response to environmental factors, stochastic processes, or immortalization procedures, which can persist even after the modifying stimulus (eg., inflammation) is removed [56]. If present, these differences could be further tested by evaluation of the methylation/acetylation patterns of DNA/histones in primary lymphocytes from monozygotic twins discordant in severity of autism or language impairment within autism which, while interesting, is beyond the scope of this study.

Regardless of origin, the gene expression differences between monozygotic twins who present with differential severity along the autism spectrum or within a specific behavioral domain (eg., language) are potentially useful, not only as biomarkers for ASD, but also as indicators of genes or metabolic/signaling pathways that may contribute to the autistic phenotype. While our short list of candidate genes (Table 4) focuses on genes with known neurological functions that are similarly up- or down-regulated across twin sets affected by ASD, the set of differentially expressed, neurologically relevant genes that are 
Table 6: Global functional analysis: Enrichment of high level functions represented in datasets of differentially expressed genes across 5 sets of monozygotic twins

\begin{tabular}{|c|c|c|c|c|c|}
\hline \multirow[t]{3}{*}{ High level function } & \multicolumn{5}{|c|}{ Significance $\left(\times 10^{2}\right)$ of enrichment of top five high level functions } \\
\hline & \multicolumn{5}{|c|}{ Twin sets } \\
\hline & $361 / 360$ & $809 / 810$ & $2369 / 2368$ & $2595 / 2596$ & $2597 / 2598$ \\
\hline $\begin{array}{l}\text { Nervous system development and } \\
\text { function }\end{array}$ & $0.008-3.85(6 / 19)^{*}$ & $0.12-2.55(3 / 7)$ & $0.8 \mathrm{I}-4.79(5 / 33)$ & $0.12-4.39(12 / 50)$ & $0.02-4.53(7 / 26)$ \\
\hline Tissue morphology & $0.008-4.27(8 / 19)$ & NAT $(0 / 7)$ & $0.81-4.79(8 / 33)$ & $0.08-4.38(18 / 50)$ & $0.51-4.03(4 / 26)$ \\
\hline Cell death & $0.01-4.27(8 / 19)$ & $3.74(1 / 7)$ & $0.09-4.79(4 / 33)$ & $0.18-4.65(12 / 50)$ & $0.09-4.53(6 / 26)$ \\
\hline Cellular development & $0.01-4.27(6 / 19)$ & NA $(0 / 7)$ & $0.8 \mathrm{I}-4.79(4 / 33)$ & $0.12-4.39(8 / 50)$ & $0.03-3.54(6 / 26)$ \\
\hline $\begin{array}{l}\text { Immune and lymphatic system } \\
\text { development and function }\end{array}$ & $0.03-3.85(9 / 19)$ & NA $(0 / 7)$ & $0.8 \mathrm{I}-4.79(10 / 33)$ & $0.33-4.39(17 / 50)$ & $0.19-4.03(9 / 26)$ \\
\hline
\end{tabular}

Global functional analysis of differential gene expression across 5 sets of monozygotic autistic twins (each pair identified by blood sample numbers (eg., $361 / 360$ ) who are discordant with respect to severity of autism or language impairment) was performed using Ingenuity's Pathways Analysis Software.

- Significance calculated for each function is an indicator of the likelihood that the high level function is associated with the dataset by random chance. The $p$-value, which is calculated using the right-tailed Fisher's Exact Test, compares the number of user-specified genes of interest (in this case, differentially expressed genes with a $\log _{2}$ (ratio) cutoff $\geq \pm 0.58$ ) that participate in a given function or pathway to the total number of occurrences of these genes in all functional/pathway annotations stored in the Ingenuity Pathways Knowledge Base. It is noteworthy that genes related to nervous system development and function rank first among the top 5 out of 74 high level functions identified in lymphoblastoid cell lines on the basis of differentially expressed genes across 5 sets of twins with autism spectrum disorders. The range of significance values for each high level function relates to the different significance values for specific subfunctions within the category.

*(number of differentially expressed genes in functional category/total number of differentially expressed network focus genes with identifiable "high level function" across 5 datasets)

INA: no significance value for this function within the dataset for this pair of twins

unique to a given twin set may also be important to the determination of a specific autistic phenotype. Indeed, comparison of the pathways represented in the respective datasets of individual twin pairs reveals not only overlapping genes but also neurologically relevant genes that are differentially expressed in only one of the twin pairs (see Additional file 2). Inasmuch as our microarray analyses directly compared genetically matched individuals who differ only in degree of expression of autistic symptoms, it is likely that other genes, not identified in our study, also play a role in the pathophysiology of autism. This experimental design possibly explains why the candidate genes identified here are different from those reported by an earlier genomic study [20] which compared autopsy brain tissues from autistic and normal (nonautistic) controls (i.e., case-control studies). On the other hand, it is interesting that many of our novel genes map closely to genetically identified autism susceptibility genes/loci or QTL (Table 7 and Additional file 4).

Aside from identifying novel candidate genes for autism, our study also illustrates the need for phenotype definition or subgrouping according to severity along a specific behavioral domain for biological studies of autism. Specifically, the results show that the differential gene expression profiles of concordantly autistic twins with differential severity of language impairment mirror some of the differences in gene expression which are observed in the twins with discordant diagnosis of autism, who also exhibit differential language deficits. Thus, for case-control studies in which individuals from the general population are compared against unrelated controls, subgrouping the autistic individuals by phenotype or stratifying them according to severity of symptoms may provide more clarity in analyzing biological data. Towards this goal, we have used several different clustering methods commonly used in DNA microarray analyses to divide over 1300 autistic individuals into endophenotypic subgroups (eg., language, nonverbal communication, and savant skills) based on item scores on the ADIR questionnaire (manuscript in preparation). Based on these methods, the twin siblings analyzed in this study, including those who were both diagnosed as autistic, each fall into different phenotypic clusters (unpublished data), with the exception of one set of twins who were discordant in the diagnosis of autism. These "endophenotypic" differences may therefore account for some of the differences in gene expression profiles between the twin siblings (i.e., cotwins) as well as among the different sets of twins. To test the ability of our clustering algorithm to restrict phenotypic and biological heterogeneity, we evaluated the short list of candidate genes in Table 4 by qPCR in an additional set of "concordant" autistic twins in which both co-twins exhibit the severely language-impaired phenotype. Results showed that, for this twin pair, there are no differences in expression of the candidate genes exceeding a $\log _{2}$ ratio of \pm 0.58 (unpublished data). 


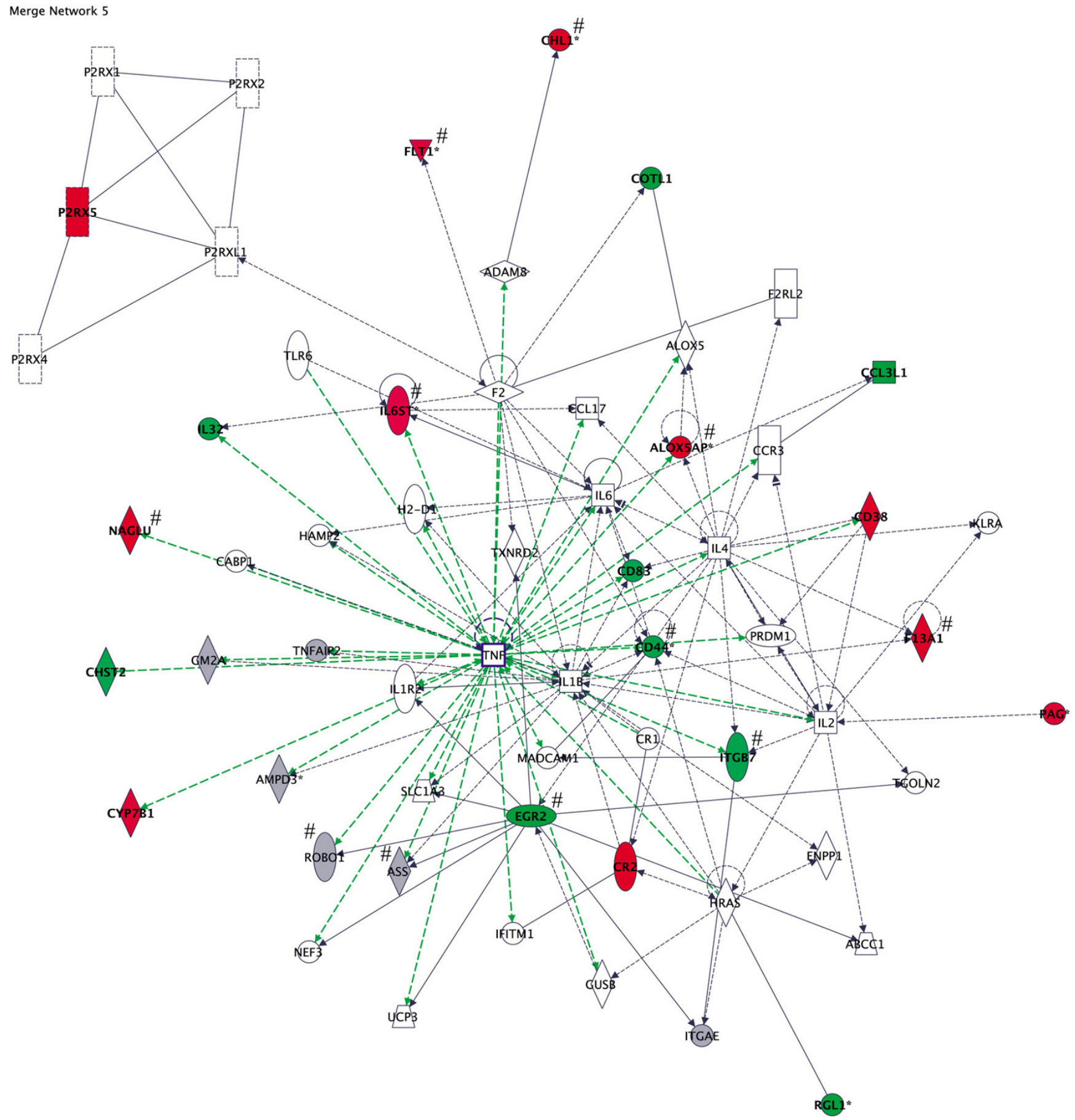

(c) 2000-2005, Ingenuity Systems

\section{Figure 2}

Gene networks showing inter-relationship between differentially expressed genes in lymphoblastoid cell lines from monozygotic twins discordant in severity of autism spectrum disorder and/or language impairment. The over-expressed (red) and under-expressed (green) genes were identified as significant using SAM analysis (FDR = I5.6\%) of microarray data across 5 twin pairs. The $\log _{2}$ expression ratio cutoff was set at \pm 0.58 and was based upon the mean values for each gene. Differentially expressed genes within this network that have a reported role in nervous system development and function are marked with a "\#" symbol and include: ALOX5AP (FLAP), CD44, CHLI, EGR2, FI3AI, FLTI, IL6ST, ITGB7, and NAGLU. Gray genes are present but do not meet expression cutoff. 
Table 7: Differentially expressed candidate genes from microarray experiments mapped in silico to autism susceptibility genes and QTL

\begin{tabular}{|c|c|c|c|c|}
\hline Candidate gene & Genbank \# & Physical Location & Reported closely mapped autism candidate genes or QTL* & Ref \\
\hline ASS & $\underline{\mathrm{AA} 676405}$ & $\operatorname{chr} 9(130,349,862-130,406,2 \mid 4)$ & dopamine beta-hydroxylase (9q34) & 77 \\
\hline $\mathrm{CHLI}$ & $\underline{\mathrm{H} I 5267}$ & $\operatorname{chr} 3(423,533-426,095)$ & KIAAOI2I (3p25.2) & 75 \\
\hline IL6R-beta, gP I 30 & $\overline{\mathrm{T} 61343}$ & $\operatorname{chr} 5(55,267,950-55,272,766)$ & Language QTL chr5:40(0-67) & 76 \\
\hline IL6ST & $\underline{\text { AA406546 }}$ & $\operatorname{chr} 5(55,271,809-55,272,305)$ & Language QTL chr5:40(0-67) & 76 \\
\hline DAPKI & Al371096 & $\operatorname{chr} 9(87,552,642-87,553,099)$ & & \\
\hline FLAP, ALOX5AP & $\overline{\mathrm{T} 49652}$ & $\operatorname{chrl} 3(30,207,643-30,236,962)$ & AUTS3 (I3qI4-22), HTR2A-2 (serotonin recep. 2A) (|3q|4-2I) & 71,72 \\
\hline ITGB7 & Al380522 & $\operatorname{chr} 12(5 I, 87|, 36|-5 I, 887,333)$ & arginine vasopressin receptor IA $(12 q \mid 4-15)$ & 69 \\
\hline EGR2 & AA446027 & $\operatorname{chrl0}(64,24 I, 755-64,246,08 I)$ & Language QTL chr 10:107(72-126); HTR-7 & 76 \\
\hline ROBOI & $\underline{\mathrm{AA} \mid 73755}$ & chr3 $(78,729,082-78,729,496)$ & & \\
\hline
\end{tabular}

\section{Conclusion}

In summary, our study indicates that LCL from genetically identical autistic individuals who differ in severity of autistic symptoms and/or language impairment exhibit differential expression of genes relevant to neurological development, structure, and function. Many of these genes map to chromosomal regions previously identified by genetic analyses as harboring autism susceptibility genes or QTL, thus demonstrating the potential of combined genomic-genetic analyses to prioritize autism candidate genes for further genetic and functional analyses. In addition, a quantitative relationship is seen between severity of symptoms and expression of several autism candidate genes when twins with classic autism or with milder autistic traits are compared against their respective normal siblings. The finding that gene expression differences were also observed in cells from twins who were both diagnosed as autistic, but who differed in severity in language deficits, strongly suggests that autistic phenotype as well as severity of symptoms must be considered in gene expression studies on autistic individuals in order to reduce biological heterogeneity due to these factors. Collectively, these studies provide proof-of-principle that LCL (and possibly their precursor peripheral blood cells) may exhibit biomarkers relevant to autism, and further suggest their potential usefulness as reporter cells in developing a diagnostic screen for autism. While it is unlikely that microarray studies on LCL will identify the etiology(ies) of autism, this global approach to gene expression analyses is expected to highlight molecular or pathway defects related to the pathophysiology of the condition which, in turn, can be targeted for drug therapies. Moreover, as opposed to fixed autopsy tissues in which RNA may have degraded, a live cell model can also be used to examine the functional consequences of the genomic alteration(s) and the efficacy of different pharmacological agents in ameliorating the impaired function.

\section{Methods}

\section{Cell lines and culture conditions}

Lymphoblastoid cell lines (LCL) derived from lymphocytes of 5 pairs of monozygotic twins with ASD were obtained from the Autism Genetic Resource Exchange (AGRE; Los Angeles, CA) and cultured in DMEM with $15 \%$ fetal bovine serum and 1\% penicillin-streptomycin. Cell lines from normal siblings of 2 sets of twins were also obtained for comparison of gene expression profile with that of their respective autistic siblings. In addition, cell lines from a set of non-autistic monozygotic twins were also studied. All LCL were constructed and maintained by the Cell Repository of the Department of Genetics at Rutgers University under contract from AGRE. To minimize differences in gene expression due to culture and sample workup conditions, all samples that underwent direct comparison of gene expression profile were cultured and harvested at the same time (3 days after passaging) using the same medium preparation and RNA isolation reagents.

\section{Description of individual donors of cell lines}

Additional file 3 provides a case description of all of the subjects included in this study. In brief, all of the twin pairs and normal siblings, with the exception of 1 set of twins, were Caucasian males between the ages of 6 and 16 at the time that blood was drawn. The remaining set of twins (age 12) was of mixed race (black, Hispanic) but had the same mother as one of the Caucasian pairs of autistic twins. For 3 sets of twins (designated "discordant" twins), one twin of each pair met standard diagnostic criteria for autism based on the Autism Diagnostic InterviewRevised (ADIR) [13]. In each case, his co-twin, while not clinically autistic, exhibited autistic traits and could be considered to be on the autism spectrum. These co-twins were described either as "Broad spectrum" or "Not quite autistic (NQA)" by the AGRE repository according to criteria established on the basis of ADI-R scores []. Gene expression in cell lines from two of these twin pairs were also directly compared against the gene expression profile in cell lines from their respective "normal" sibling. Two of 
the 5 sets of twins with ASD (designated "concordant" twins) were examples in which both co-twins were diagnosed with autism, but who were discordant in severity of language impairment, as indicated by their respective percentile scores on the Peabody Picture Vocabulary Test (PPVT). The Autism Diagnostic Observation Schedule (ADOS) [14] was used to diagnose one of these sets of twins. None of the individuals whose cells were used presented with any co-morbid condition or mental retardation. All of the phenotypic data were obtained through the AGRE databases [].

\section{DNA microarray analyses}

RNA was isolated from the LCL using TRIzol Reagent (Invitrogen, CA) according to the manufacturer's protocol. The RNA was further purified using Centricon YM-30 columns and tested for purity on RNA 6000 NanoChips using the Agilent 2100 Bioanalyzer. Labeled cDNA was obtained by incorporation of 5-(3-aminoallyl)-2'deoxyuridine-5'-triphosphate (Ambion, TX) during first-strand synthesis, followed by coupling to the ester of cyanine (Cy-3 or Cy-5) (Molecular Probes, OR) as appropriate according to Standard Operating Protocol (SOP) M004 on The Institute for Genomic Research (TIGR) website []. For two-color microarray analyses, the Cy5- and Cy3labeled cDNA from each pair of twins (or twin and normal sib) were co-hybridized using TIGR SOP M005 to spotted microarrays (TIGR 40 K Human Set) containing 39,936 human cDNA probes which were obtained from Research Genetics. Dye reversal (flip-dye) replicates were included in all analyses, and at least 2 sets of replicates were carried out for each pair of monozygotic twins. Gene expression levels were derived from the scanned hybridized arrays using a combination of TIGR SpotFinder, MIDAS, and MeV analysis programs which are all part of the TM4 Microarray Analysis Software Package available at the above-cited website. These programs have all been previously described in detail [57]. Data analyses included normalization using local LOWESS followed by standard deviation regularization across individual subarrays, and flip-dye consistency checking for dye reversal replicates as implemented in MIDAS $[27,58]$. The SAM (Significance Analysis of Microarrays) module within $\mathrm{MeV}$ was used to determine statistical significance of differential gene expression and false discovery rate (FDR) which corrects for multiple testing.

\section{Quantitative RT-PCR}

Total RNA (same preparations used in microarray analyses) was reverse transcribed into cDNA using the iScript cDNA Synthesis Kit (Bio-Rad, Hercules, CA). Briefly, $2 \mu \mathrm{g}$ of RNA were added to a $40 \mu \mathrm{l}$ reaction mix containing reaction buffer, magnesium chloride, dNTPs, an optimized blend of random primers and oligo(dT), an RNase inhibitor, and a MMLV RNase $\mathrm{H}+$ reverse transcriptase.
The reaction was incubated at $25^{\circ} \mathrm{C}$ for 5 minutes followed by $42^{\circ} \mathrm{C}$ for 30 minutes and ending with $85^{\circ} \mathrm{C}$ for 5 minutes. The cDNA reactions were then diluted to a volume of $100 \mu \mathrm{l}$ with water. Real-time PCR was carried out either on a 7900 HT Sequence Detection System from Applied Biosystems using the iTaq SYBR Green Supermix with ROX (Bio-Rad, Hercules, CA) or an Applied Biosystems 7300 Real-Time PCR system using Invitrogen's Superscript III Platinum SYBR Green Two-step qRT-PCR Kit with ROX. Gene-specific primers at a final concentration of $200 \mathrm{nM}$ and $1 \mu \mathrm{l}$ of cDNA templates were combined into $20 \mu \mathrm{l}$ reaction mixes and run through 40 cycles of PCR. Quantitation was performed using the Universal $18 \mathrm{~S}$ rRNA primers (Ambion, Austin, TX) with samples normalized to their $18 \mathrm{~S}$ rRNA standard curves. Forward and reverse primers are described in Additional file 5.

\section{Network prediction analyses}

Lists of differentially expressed genes identified as "significant" by SAM analysis of microarray data across different sets of twins were analyzed using Ingenuity Pathways Analysis (Ingenuity Systems, Inc.), a web-delivered application that enables biologists to discover, visualize and explore therapeutically relevant networks significant to their specific experimental results (e.g., gene expression array data sets). Specifically, a data set containing gene identifiers (in this case, GenBank Accessions) and their corresponding expression values were uploaded as an Excel spreadsheet using the template provided in the application. Each gene identifier was mapped to its corresponding gene object in the Ingenuity Pathways Knowledge Base. The gene list was filtered prior to analysis with Ingenuity by using a $\log _{2}$ (ratio) cutoff of 0.58 . These genes were then used as the starting point for generating biological networks. The networks are displayed graphically as nodes (genes/gene products) and edges (the biological relationships between the nodes). Human, mouse, and rat orthologs of a gene are stored as separate objects in the knowledge base, but are represented as a single node in the network. The intensity of the node color indicates the degree of up- (red) or down- (green) regulation. When networks from different samples are merged (as in Additional file 2), yellow node color denotes overlapping differentially expressed genes from two or more samples. Nodes are displayed using various shapes that represent the functional class of the gene product, as described on Ingenuity's website [].

\section{Global functional analyses}

Biological functions were assigned to the overall analysis (across data from 5 monozygotic twin pairs) by using the findings that have been extracted from the scientific literature and stored in the Ingenuity Pathways Knowledge Base []. The biological functions assigned to the analysis are ranked according to the significance of that biological 
function to the analysis. A Fisher's exact test is used to calculate a $p$-value determining the probability that the biological function assigned to the analysis is explained by chance alone. Again, a differential expression cutoff of $\log _{2}$ (ratio) $\geq \pm 0.58$ was used.

\section{In silico mapping of differentially expressed genes}

The physical locations of each of the significant differentially expressed genes with $\log 2$ (ratio) $\geq \pm 0.58$ were obtained using TIGR's Resourcerer Gene Annotation Software []. These locations were then compared manually to those of autism candidate genes (ACG) or quantitative trait loci (QTL) identified on the basis of published genetic linkage and association studies [59-78]. For comparison, using Human Genome Build 35 and defining genes as the collection annotated by Ensembl (a total of 24974), we have found that the set of non-redundant genes mapping to the large, often overlapping autism susceptibility or QTL regions is 3838 , or about $15.4 \%$ of the total.

Submission of microarray data to GEO repository

The GEO accession number for all of the microarray data is GSE4187.

\section{Abbreviations}

ACG: autism candidate genes

ADIR: Autism Diagnostic Interview-Revised

ADOS: Autism Diagnostic Observation Schedule

AGRE: Autism Genetic Resource Exchange

ASD: autism spectrum disorders

ASS: argininosuccinate synthetase

CHL1: cell adhesion molecule with homology to L1CAM

DAPK1: death-associated protein kinase 1

EGR2: early growth response 2 protein (Krox-20)

FLAP: 5-lipoxygenase activating protein

FLT1: Fms-related tyrosine kinase 1 (VEGF receptor)

5-HTT: 5-hydroxytryptamine (serotonin) transporter

ITGB7: integrin beta-7

LCL: lymphoblastoid cell lines

PPVT: Peabody Picture Vocabulary Test
PTGS2: prostaglandin-endoperoxide synthase 2 (cyclooxygenase-2, COX-2)

QTL: quantitative trait loci

ROBO1: roundabout, axon guidance receptor

SAM: Significance Analysis of Microarrays

\section{Authors' contributions}

VWH conceived of the study and experimental design using monozygotic twins discordant in autism. She also carried out the sample preparations, DNA microarray hybridizations, data analyses, and manuscript preparation. JQ and NHL provided helpful advice with regard to microarray data analyses and also contributed to manuscript preparation. BCF and SH were responsible for the confirmatory qRT-PCR analyses. All authors read and approved the final manuscript.

\section{Additional material}

\begin{abstract}
Additional File 1
Principal components analysis of microarray data from the 5 sets of monozygotic twins with ASD, with each color representing a separate pair of twins. This figure shows that genotype is a major contributor to variations in overall gene expression profile. Each point on the graph represents a dye-reversal experiment on a given twin pair. Note that even the 2 pairs of twins who share the same mother but have different fathers (pink and yellow points) are distinguishable from each other.

Click here for file

[http://www.biomedcentral.com/content/supplementary/14712164-7-118-S1.jpeg]
\end{abstract}

\section{Additional File 2}

A representative gene network showing overlap of some neurologically relevant genes among 3 discordant autistic twin sets using Ingenuity Pathways Analysis software. Genes shown in yellow represent overlap of differentially expressed genes in 2 or more sets of twins, whereas the red and green nodes correspond to genes that are up-or down-regulated, respectively, in only 1 twin set. The expression cutoff was set at $\log _{2}$ (ratio) $= \pm 0.58$ for each twin set. The 12 genes marked by "\#" are known to be involved in nervous system development and function.

Click here for file

[http://www.biomedcentral.com/content/supplementary/14712164-7-118-S2.jpeg]

\section{Additional File 3}

Case description of subjects from whom LCL were derived and used in this study. (Self-explanatory)

Click here for file

[http://www.biomedcentral.com/content/supplementary/14712164-7-118-S3.pdf] 


\section{Additional File 4}

Differentially expressed genes within or across twin sets mapped within or close to autism candidate genes or quantitative trait loci. This table shows that many of the differentially expressed genes map in silico to autism susceptibility loci or quantitative trait loci identified by genetic analyses.

Click here for file

[http://www.biomedcentral.com/content/supplementary/1471-

2164-7-118-S4.pdf]

\section{Additional File 5}

Primers used for quantitative RT-PCR analyses. (Self-explanatory) Click here for file

[http://www.biomedcentral.com/content/supplementary/14712164-7-118-S5.pdf]

\section{Acknowledgements}

We gratefully acknowledge the resources provided by the Autism Genetic Resource Exchange (AGRE) Consortium* and the participating AGRE families. The Autism Genetic Resource Exchange is a program of Cure Autism Now and is supported, in part, by grant MH64547 from the National Institute of Mental Health to Daniel H. Geschwind (PI).

\section{*The AGRE Consortium:}

Dan Geschwind, M.D., Ph.D., UCLA, Los Angeles, CA;

Maja Bucan, Ph.D., University of Pennsylvania, Philadelphia, PA;

W.Ted Brown, M.D., Ph.D., F.A.C.M.G., N.Y.S. Institute for Basic Research in Developmental Disabilities, Long Island, NY;

Rita M. Cantor, Ph.D., UCLA School of Medicine, Los Angeles, CA;

John N. Constantino, M.D., Washington University School of Medicine, St. Louis, MO;

T.Conrad Gilliam, Ph.D., University of Chicago, Chicago, IL;

Clara Lajonchere, Ph.D, Cure Autism Now, Los Angeles, CA;

David H. Ledbetter, Ph.D., Emory University, Atlanta, GA;

Christa Lese-Martin, Ph.D., Emory University, Atlanta, GA;

Janet Miller, J.D., Ph.D., Cure Autism Now, Los Angeles, CA;

Stanley F. Nelson, M.D., UCLA School of Medicine, Los Angeles, CA;

Gerard D. Schellenberg, Ph.D., University of Washington, Seattle, WA;

Carol A. Samango-Sprouse, Ed.D., George Washington University, Washington, D.C.;

Sarah Spence, M.D., Ph.D., UCLA, Los Angeles, CA;

Matthew State, M.D., Ph.D., Yale University, New Haven, CT.

Rudolph E. Tanzi, Ph.D., Massachusetts General Hospital, Boston, MA.
We also thank Dr. Vlad Kustanovich of AGRE for providing us with a comprehensive list of reported genetic markers for autism and Dr. Timothy McCaffrey for helpful discussions. This study was supported by a pilot grant from the Catharine Birch McCormick Genomics Center (VWH).

\section{References}

I. American Psychiatric Association., American Psychiatric Association. Task Force on DSM-IV.: Diagnostic and statistical manual of mental disorders : DSM-IV. 4th edition. Washington, D.C. , American Psychiatric Association; 1994:xxvii, 886 p.

2. Crino PB, Henske EP: New developments in the neurobiology of the tuberous sclerosis complex. Neurology 1999, 53(7): $1384-1390$

3. Bolton PF: Neuroepileptic correlates of autistic symptomatology in tuberous sclerosis. Ment Retard Dev Disabil Res Rev 2004, IO(2):|26-|3|.

4. Kandt RS, Haines JL, Smith M, Northrup H, Gardner RJ, Short MP, Dumars K, Roach ES, Steingold S, Wall S, Blanton SH, Flodman P, Kwiatkowski DJ, Jewell A, Weber JL, Roses AD, Pericak-Vance MA: Linkage of an important gene locus for tuberous sclerosis to a chromosome 16 marker for polycystic kidney disease. Nat Genet 1992, 2(1):37-4I.

5. Identification and characterization of the tuberous sclerosis gene on chromosome 16. The European Chromosome 16 Tuberous Sclerosis Consortium. Cell 1993, 75(7): | 305-1315.

6. Kandt RS: Tuberous sclerosis: the next step. J Child Neurol 1993 , 8(2): 107-10; discussion II0-I.

7. Mulley JC, Sutherland GR: Integrating maps of chromosome 16. Curr Opin Genet Dev 1993, 3(3):425-431.

8. van Slegtenhorst $M$, de Hoogt $R$, Hermans $C$, Nellist $M$, Janssen $B$, Verhoef S, Lindhout D, van den Ouweland A, Halley D, Young J, Burley M, Jeremiah S, Woodward K, Nahmias J, Fox M, Ekong R, Osborne J, Wolfe J, Povey S, Snell RG, Cheadle JP, Jones AC, Tachataki M, Ravine D, Sampson JR, Reeve MP, Richardson P, Wilmer F, Munro C, Hawkins TL, Sepp T, Ali JB, Ward S, Green AJ, Yates JR, Kwiatkowska J, Henske EP, Short MP, Haines JH, Jozwiak S, Kwiatkowski DJ: Identification of the tuberous sclerosis gene TSCI on chromosome 9q34. Science 1997, 277(5327):805-808.

9. Henske EP, Ozelius L, Gusella JF, Haines JL, Kwiatkowski DJ: A highresolution linkage map of human 9q34.I. Genomics 1993, I7(3):587-59|.

10. [Epigenetic study of Rett's syndrome as an adequate model for autistic disorders]. Zh Nevrol Psikhiatr Im S S Korsakova 2005, 105(7):4-II.

II. Gedeon AK, Baker E, Robinson H, Partington MW, Gross B, Manca A, Korn B, Poustka A, Yu S, Sutherland GR, Mulley JC: Fragile $\mathbf{X}$ syndrome without CCG amplification has an FMR I deletion. Nat Genet 1992, I(5):34I-344.

12. Hansen RS, Gartler SM, Scott CR, Chen SH, Laird CD: Methylation analysis of CGG sites in the CpG island of the human FMRI gene. Hum Mol Genet 1992, I(8):57I-578.

13. Lord C, Rutter M, Le Couteur A: Autism Diagnostic InterviewRevised: a revised version of a diagnostic interview for caregivers of individuals with possible pervasive developmental disorders. J Autism Dev Disord 1994, 24(5):659-685.

14. Lord C, Rutter M, Goode S, Heemsbergen J, Jordan H, Mawhood L, Schopler E: Autism diagnostic observation schedule: a standardized observation of communicative and social behavior. Autism Dev Disord 1989, 19(2):185-21 2.

15. Yonan AL, Palmer AA, Smith KC, Feldman I, Lee HK, Yonan JM, Fischer SG, Pavlidis P, Gilliam TC: Bioinformatic analysis of autism positional candidate genes using biological databases and computational gene network prediction. Genes Brain Behav 2003, 2(5):303-320.

16. Geschwind DH: DNA microarrays: translation of the genome from laboratory to clinic. Lancet Neurol 2003, 2(5):275-282.

17. Schena M, Shalon D, Davis RW, Brown PO: Quantitative monitoring of gene expression patterns with a complementary DNA microarray. Science 1995, 270(5235):467-470.

18. Lipshutz RJ, Fodor SP, Gingeras TR, Lockhart DJ: High density synthetic oligonucleotide arrays. Nat Genet 1999, 2 I(I Suppl):20-24.

19. Pongrac J, Middleton FA, Lewis DA, Levitt P, Mirnics K: Gene expression profiling with DNA microarrays: advancing our 
understanding of psychiatric disorders. Neurochem Res 2002, 27(10): 1049-1063.

20. Purcell AE, Jeon OH, Zimmerman AW, Blue ME, Pevsner J: Postmortem brain abnormalities of the glutamate neurotransmitter system in autism. Neurology 200I, 57(9):1618-1628.

21. Cheung VG, Conlin LK, Weber TM, Arcaro M, Jen KY, Morley M, Spielman RS: Natural variation in human gene expression assessed in lymphoblastoid cells. Nat Genet 2003, 33(3):422-425.

22. Sharma A, Sharma VK, Horn-Saban S, Lancet D, Ramachandran S, Brahmachari SK: Assessing natural variations in gene expression in humans by comparing with monozygotic twins using microarrays. Physiol Genomics 2005, 21(I): I I7-123.

23. Kakiuchi $C$, Iwamoto $K$, Ishiwata $M$, Bundo $M$, Kasahara $T$, Kusumi I, Tsujita T, Okazaki Y, Nanko S, Kunugi H, Sasaki T, Kato T: Impaired feedback regulation of XBPI as a genetic risk factor for bipolar disorder. Nat Genet 2003, 35(2): $17 \mid-175$.

24. Mak YT, Hampson G, Beresford JN, Spector TD: Variations in genome-wide gene expression in identical twins - a study of primary osteoblast-like culture from female twins discordant for osteoporosis. BMC Genet 2004, 5(I):14.

25. Iwamoto K, Kakiuchi C, Bundo M, Ikeda K, Kato T: Molecular characterization of bipolar disorder by comparing gene expression profiles of postmortem brains of major mental disorders. Mol Psychiatry 2004, 9(4):406-4I6.

26. Kato $T$, Iwayama $Y$, Kakiuchi $C$, Iwamoto $K$, Yamada $K$, Minabe $Y$, Nakamura K, Mori N, Fujii K, Nanko S, Yoshikawa T: Gene expression and association analyses of LIM (PDLIM5) in bipolar disorder and schizophrenia. Mol Psychiatry 2005.

27. Yang IV, Chen E, Hasseman JP, Liang W, Frank BC, Wang S, Sharov V, Saeed Al, White J, Li J, Lee NH, Yeatman T], Quackenbush J: Within the fold: assessing differential expression measures and reproducibility in microarray assays. Genome Biol 2002, 3(II):research0062

28. Coutinho AM, Oliveira G, Morgadinho T, Fesel C, Macedo TR, Bento C, Marques C, Ataide A, Miguel T, Borges L, Vicente AM: Variants of the serotonin transporter gene (SLC6A4) significantly contribute to hyperserotonemia in autism. Mol Psychiatry 2004 9(3):264-27I.

29. Bradley SL, Dodelzon K, Sandhu HK, Philibert RA: Relationship of serotonin transporter gene polymorphisms and haplotypes to mRNA transcription. Am J Med Genet B Neuropsychiatr Genet 2005, I36(I):58-6I

30. Lesch KP, Bengel D, Heils A, Sabol SZ, Greenberg BD, Petri S, Benjamin J, Muller CR, Hamer DH, Murphy DL: Association of anxiety-related traits with a polymorphism in the serotonin transporter gene regulatory region. Science 1996, 274(5292): I527-|53|.

31. Hattori Y, Campbell EB, Gross SS: Argininosuccinate synthetase mRNA and activity are induced by immunostimulants in vascular smooth muscle. Role in the regeneration or arginine for nitric oxide synthesis. J Biol Chem 1994, 269(13):9405-9408.

32. Akyol O, Zoroglu SS, Armutcu F, Sahin S, Gurel A: Nitric oxide as a physiopathological factor in neuropsychiatric disorders. In Vivo 2004, 18(3):377-390.

33. Heneka MT, Schmidlin A, Wiesinger $\mathrm{H}$ : Induction of argininosuccinate synthetase in rat brain glial cells after striatal microinjection of immunostimulants. J Cereb Blood Flow Metab 1999 1 9(8):898-907.

34. Vargas DL, Nascimbene C, Krishnan C, Zimmerman AW, Pardo CA: Neuroglial activation and neuroinflammation in the brain of patients with autism. Ann Neurol 2005, 57(I):67-8I.

35. Wang WJ, Kuo JC, Yao CC, Chen RH: DAP-kinase induces apoptosis by suppressing integrin activity and disrupting matrix survival signals. / Cell Biol 2002, I 59(I): 169-179.

36. Gupta S: A decision between life and death during TNF-alphainduced signaling. I Clin Immunol 2002, 22(4): I85-194.

37. Frank S, Stallmeyer B, Kampfer H, Schaffner C, Pfeilschifter J: Differential regulation of vascular endothelial growth factor and its receptor fms-like-tyrosine kinase is mediated by nitric oxide in rat renal mesangial cells. Biochem J 1999, 338 ( Pt 2):367-374.

38. Byrum RS, Goulet JL, Griffiths RJ, Koller BH: Role of the 5-lipoxygenase-activating protein (FLAP) in murine acute inflammatory responses. J Exp Med 1997, I 85(6): 1065-1075.
39. Pokharel YR, Yang JW, Kim JY, Oh HW, Jeong HG, Woo ER, Kang $\mathrm{KW}$ : Potent inhibition of the inductions of inducible nitric oxide synthase and cyclooxygenase- 2 by taiwaniaflavone. Nitric Oxide 2006.

40. Manev H, Uz T, Sugaya K, Qu T: Putative role of neuronal 5lipoxygenase in an aging brain. Faseb J 2000, I4( I 0): I 464-I 469

4I. Manev R, Manev H: 5-Lipoxygenase as a putative link between cardiovascular and psychiatric disorders. Crit Rev Neurobiol 2004, I6(I-2):181-186.

42. Muller N, Schwarz MJ, Dehning S, Douhe A, Cerovecki A, GoldsteinMuller B, Spellmann I, Hetzel G, Maino K, Kleindienst N, Moller HJ, Arolt $V$, Riedel M: The cyclooxygenase-2 inhibitor celecoxib has therapeutic effects in major depression: results of a double-blind, randomized, placebo controlled, add-on pilot study to reboxetine. Mol Psychiatry 2006.

43. Cohly $\mathrm{HH}$, Panja $\mathrm{A}$ : Immunological findings in autism. Int Rev Neurobiol 2005, 71:3 17-34I.

44. Kamholz J, Awatramani R, Menichella D, jiang H, Xu W, Shy M: Regulation of myelin-specific gene expression. Relevance to CMTI. Ann N Y Acad Sci 1999, 883:91-108.

45. LeBlanc SE, Jang SW, Ward RM, Wrabetz L, Svaren J: Direct regulation of myelin protein zero expression by the Egr2 transactivator. I Biol Chem 2006, 28 I (9):5453-5460.

46. Connor RM, Key B: Expression and role of Roundabout-I in embryonic Xenopus forebrain. Dev Dyn 2002, 225(I):22-34

47. Lee JS, Ray R, Chien CB: Cloning and expression of three zebrafish roundabout homologs suggest roles in axon guidance and cell migration. Dev Dyn 200I, 22 I (2):216-230.

48. Kanwar JR, Harrison JE, Wang D, Leung E, Mueller W, Wagner N, Krissansen GW: Beta7 integrins contribute to demyelinating disease of the central nervous system. I Neuroimmunol 2000, 103(2): | $46-152$.

49. Buhusi M, Midkiff BR, Gates AM, Richter M, Schachner M, Maness PF: Close homolog of $L I$ is an enhancer of integrin-mediated cell migration. J Biol Chem 2003, 278(27):25024-2503I.

50. Naus S, Richter M, Wildeboer D, Moss M, Schachner M, Bartsch JW: Ectodomain shedding of the neural recognition molecule CHLI by the metalloprotease-disintegrin ADAM8 promotes neurite outgrowth and suppresses neuronal cell death. J Biol Chem 2004, 279(16): 16083-16090.

5I. Abdolmaleky HM, Thiagalingam S, Wilcox M: Genetics and epigenetics in major psychiatric disorders: dilemmas, achievements, applications, and future scope. Am J Pharmacogenomics 2005, 5(3): 149-160.

52. Petronis A, Gottesman II, Kan P, Kennedy JL, Basile VS, Paterson AD Popendikyte V: Monozygotic twins exhibit numerous epigenetic differences: clues to twin discordance? Schizophr Bull 2003, 29(I):169-178.

53. Petronis A: Epigenetics and bipolar disorder: new opportunities and challenges. Am J Med Genet C Semin Med Genet 2003, I 23(I):65-75.

54. Amir RE, Van den Veyver IB, Wan M, Tran CQ, Francke U, Zoghbi HY: Rett syndrome is caused by mutations in $\mathbf{X}$-linked MECP2, encoding methyl-CpG-binding protein 2. Nat Genet 1999, 23(2): $185-188$.

55. $\mathrm{Nan} X, \mathrm{Ng} \mathrm{HH}$, Johnson CA, Laherty $\mathrm{CD}$, Turner BM, Eisenman RN Bird A: Transcriptional repression by the methyl-CpG-binding protein MeCP2 involves a histone deacetylase complex. Nature 1998, 393(6683):386-389.

56. Jablonka $E$, Lamb MJ: The changing concept of epigenetics. Ann N Y Acad Sci 2002, 981:82-96.

57. Saeed Al, Sharov V, White J, Li J, Liang W, Bhagabati N, Braisted J, Klapa M, Currier T, Thiagarajan M, Sturn A, Snuffin M, Rezantsev A, Popov D, Ryltsov A, Kostukovich E, Borisovsky I, Liu Z, Vinsavich A, Trush V, Quackenbush J: TM4: a free, open-source system for microarray data management and analysis. Biotechniques 2003 , 34(2):374-378

58. Quackenbush J: Microarray data normalization and transformation. Nat Genet 2002, 32 Suppl:496-50I.

59. Smith M, Filipek PA, Wu C, Bocian M, Hakim S, Modahl C, Spence MA Analysis of a $\mathrm{I}$-megabase deletion in 15q22-q23 in an autistic patient: identification of candidate genes for autism and of homologous DNA segments in 15q22-q23 and |5q||-q|3. Am J Med Genet 2000, 96(6):765-770.

60. Bartlett CW, Goedken R, Vieland V]: Effects of updating linkage evidence across subsets of data: reanalysis of the autism 
genetic resource exchange data set. Am J Hum Genet 2005, 76(4):688-695.

61. Shao Y, Cuccaro ML, Hauser ER, Raiford KL, Menold MM, Wolpert CM, Ravan SA, Elston L, Decena K, Donnelly SL, Abramson RK, Wright HH, DeLong GR, Gilbert JR, Pericak-Vance MA: Fine mapping of autistic disorder to chromosome $|5 q \mathrm{I}|-\mathrm{q} \mid 3$ by use of phenotypic subtypes. Am J Hum Genet 2003, 72(3):539-548.

62. A full genome screen for autism with evidence for linkage to a region on chromosome 7q. International Molecular Genetic Study of Autism Consortium. Hum Mol Genet 1998, 7(3):57I-578.

63. Risch N, Spiker D, Lotspeich L, Nouri N, Hinds D, Hallmayer J, Kalaydjieva L, McCague P, Dimiceli S, Pitts T, Nguyen L, Yang J, Harper C, Thorpe D, Vermeer S, Young H, Hebert J, Lin A, Ferguson J, Chiotti C, Wiese-Slater S, Rogers T, Salmon B, Nicholas P, Petersen PB, Pingree C, McMahon W, Wong DL, Cavalli-Sforza LL, Kraemer HC, Myers RM: A genomic screen of autism: evidence for a multilocus etiology. Am J Hum Genet 1999, 65(2):493-507.

64. Serajee FJ, Zhong H, Nabi R, Huq AH: The metabotropic glutamate receptor 8 gene at 7q3 I: partial duplication and possible association with autism. J Med Genet 2003, 40(4):e42.

65. Gharani N, Benayed R, Mancuso V, Brzustowicz LM, Millonig JH: Association of the homeobox transcription factor, ENGRAILED 2, 3, with autism spectrum disorder. Mol Psychiatry 2004, 9(5):474-484.

66. Bacchelli E, Blasi F, Biondolillo M, Lamb JA, Bonora E, Barnby G, Parr J, Beyer KS, Klauck SM, Poustka A, Bailey AJ, Monaco AP, Maestrini E: Screening of nine candidate genes for autism on chromosome $2 \mathrm{q}$ reveals rare nonsynonymous variants in the CAMP. GEFII gene. Mol Psychiatry 2003, 8(I I):916-924.

67. Cantor RM, Kono N, Duvall JA, Alvarez-Retuerto A, Stone IL, Alarcon M, Nelson SF, Geschwind DH: Replication of autism linkage: fine-mapping peak at 17q2I. Am J Hum Genet 2005, 76(6): $1050-1056$

68. Sultana R, Yu CE, Yu J, Munson J, Chen D, Hua W, Estes A, Cortes F, de la Barra F, Yu D, Haider ST, Trask B], Green ED, Raskind WH, Disteche CM, Wijsman E, Dawson G, Storm DR, Schellenberg GD, Villacres EC: Identification of a novel gene on chromosome 7 q I I.2 interrupted by a translocation breakpoint in a pair of autistic twins. Genomics 2002, 80(2): 129-134.

69. Wassink TH, Brzustowicz LM, Bartlett CW, Szatmari P: The search for autism disease genes. Ment Retard Dev Disabil Res Rev 2004, I 0(4):272-283.

70. Persico AM, D'Agruma L, Zelante L, Militerni R, Bravaccio C, Schneider C, Melmed R, Trillo S, Montecchi F, Elia M, Palermo M, Rabinowitz D, Pascucci T, Puglisi-Allegra S, Reichelt KL, Muscarella L, Guarnieri V, Melgari JM, Conciatori M, Keller F: Enhanced APOE2 transmission rates in families with autistic probands. Psychiatr Genet 2004, 14(2):73-82.

7I. Veenstra-VanderWeele J, Kim SJ, Lord C, Courchesne R, Akshoomoff $\mathrm{N}$, Leventhal BL, Courchesne E, Cook EHJ: Transmission disequilibrium studies of the serotonin 5-HT2A receptor gene (HTR2A) in autism. Am J Med Genet 2002, I l 4(3):277-283.

72. Bradford Y, Haines J, Hutcheson H, Gardiner M, Braun T, Sheffield V, Cassavant T, Huang W, Wang K, Vieland V, Folstein S, Santangelo S, Piven J: Incorporating language phenotypes strengthens evidence of linkage to autism. Am J Med Genet 200I, 105(6):539-547.

73. Chen GK, Kono N, Geschwind DH, Cantor RM: Quantitative trait locus analysis of nonverbal communication in autism spectrum disorder. Mol Psychiatry 2005.

74. Persico AM, D'Agruma L, Maiorano N, Totaro A, Militerni R, Bravaccio C, Wassink TH, Schneider C, Melmed R, Trillo S, Montecchi F, Palermo M, Pascucci T, Puglisi-Allegra S, Reichelt KL, Conciatori $M$, Marino R, Quattrocchi CC, Baldi A, Zelante L, Gasparini P, Keller F: Reelin gene alleles and haplotypes as a factor predisposing to autistic disorder. Mol Psychiatry 200I, 6(2):150-159.

75. A genomewide screen for autism: strong evidence for linkage to chromosomes 2q, 7q, and 16p. Am J Hum Genet 200I, 69(3):570-58I.

76. Alarcon M, Yonan AL, Gilliam TC, Cantor RM, Geschwind DH: Quantitative genome scan and Ordered-Subsets Analysis of autism endophenotypes support language QTLs. Mol Psychiatry 2005, I 0(8):747-757.

77. Robinson PD, Schutz CK, Macciardi F, White BN, Holden J]: Genetically determined low maternal serum dopamine beta- hydroxylase levels and the etiology of autism spectrum disorders. Am J Med Genet 200I, I00(I):30-36.

78. Alarcon M, Cantor RM, Liu J, Gilliam TC, Geschwind DH: Evidence for a language quantitative trait locus on chromosome 7q in multiplex autism families. Am J Hum Genet 2002, 70(I):60-7I.

79. [http://www.agre.org]

80. [http://www.tigr.org].

8I. [http://www.ingenuity.com].
Publish with Biomed Central and every scientist can read your work free of charge

"BioMed Central will be the most significant development for disseminating the results of biomedical research in our lifetime. "

Sir Paul Nurse, Cancer Research UK

Your research papers will be:

- available free of charge to the entire biomedical community

- peer reviewed and published immediately upon acceptance

- cited in PubMed and archived on PubMed Central

- yours - you keep the copyright

Submit your manuscript here:

http://www.biomedcentral.com/info/publishing_adv.asp
BioMedcentral 